\title{
Unmoderated Remote Usability Testing: An Approach during Covid-19 Pandemic
}

\author{
Ambar Relawati ${ }^{1}$, Yanuar Primanda ${ }^{3}$ \\ School of Nursing, Universitas Muhammadiyah Yogyakarta \\ Yogyakarta, Indonesia
}

\author{
Guntur Maulana Zamroni ${ }^{2}$ \\ Department of Informatics Engineering \\ Universitas Ahmad Dahlan, Yogyakarta, Indonesia
}

\begin{abstract}
Online Nurse Test for Indonesian Nurse Competency (ONT UKNI) is a mobile application that was developed to help increase the success rate of nurse competency test participants. By using this application, users can learn more about the materials tested and conduct try out as a competency test simulation. However, ONT UKNI has not yet passed adequate testing stages, especially in terms of User Interface/User Experience (UI/UX). The Covid-19 pandemic situation presents challenges in the UI/UX testing process. Testing process which is ideally carried out face-to-face with respondents to get further insight, have to be carried out using another approach following the new normal protocol. This study aims to test the usability of UI/UX with an unmoderated remote testing approach on ONT UKNI application using a USE questionnaire. The test was performed using 26 respondents and all were nursing profession students of Universitas Muhammadiyah Yogyakarta. Respondents performed 8 tasks on ONT UKNI and answered set of questionnaire that will be tabulated and analyzed. The results indicate that usefulness, ease of learning, and satisfaction variables get the Very Good category while the ease of use variable gets the Good category. Overall, usability testing using an unmoderated remote testing approach can be carried out and able to provide information about areas where users are satisfied with ONT UKNI application. However, some areas still have room for improvement such as better UI design and implementation of gamification.
\end{abstract}

Keywords-Mobile learning; nurse competency test; unmoderated remote testing; usability

\section{INTRODUCTION}

Mobile-based learning media is not a new thing in an effort to improve the quality of educational outcomes. Rapid growth of mobile technology and its application gradually replace the role of computer [1]. The author in [2] conducted research on the effectiveness of using Android-based learning media for biology subjects in high school students. From the research conducted, it is known that the learning media has a positive impact. Android-based learning media increases interest and motivation in learning which indirectly increases the effectiveness of learning outcomes. Android-based learning media provides several advantages such as attractive designs, both in terms of images, colors, and writing. Learning media is also easy to use independently either at school or outside of school. In another study conducted by [3], it is known that school students are easier to accept learning materials in digital form than in written or oral form. Digital learning media such as Android-based learning media application have several advantages, such as ease of use, can be used for learning anywhere, and can be used offline [4]. This shows that mobile applications are increasingly popular for use in education area.

Online Nurse Test for Indonesian Nurse Competency (ONT UKNI) is a mobile application that was developed and aimed to increasing the success rate of nurse competency test participants [5]. By using this application, users -in this case are nursing profession students- can learn about the materials tested at competency test and conduct try out as competency test simulations. However, ONT UKNI has not passed adequate testing stages, especially in terms of user experience or User Interface / User Experience (UI/UX). This is important because user experience determines the success or failure of a product [6]. If product's usability cannot satisfy user, it will hinder the overall quality of the application. Thus developer should consider usability when design an application so it will meet its purpose [7]. Furthermore, [8] added that the mobile app needs to go through a thorough testing phase due to several factors such as the limited screen size. For this reason, it is necessary to conduct user-oriented testing to ensure feasibility and user experience.

Usability testing can be used to test feasibility and user experience [9]. The author in [10] conducted research related to usability testing on the online guardianship application STMIK AMIK Bandung by using a USE questionnaire as a research instrument. Although USE questionnaire lack of evidence in reliability and validity, it provides insight for researchers in terms of usefulness, satisfaction, and ease of use [11][12]. The author in [13] conducted usability testing research on YouTube websites among Malaysian teenagers using the same 3 criteria, namely usefulness, satisfaction, and ease of use. Apart from the USE questionnaire, there are also several other usability testing instruments, such as the User Experience Questionnaire (UEQ) and the System Usability Scale (SUS) [14][15]. The author in [16] performed usability testing on the MyTelkomsel mobile application using 5 criteria, namely: learnability, efficiency, memorability, error, and satisfaction. The data collection technique used was a survey with SUS instrument, observation, and direct interviews. Based on this research, it can be seen that the interview technique helped researchers to get further insight and find solutions to the problems that respondents complains about the MyTelkomsel application. The author in [17] also used a survey and interview techniques in usability testing with certain variables, such as demographic information, using experience, ease of use, and usefulness.

The Covid-19 pandemic situation presents challenges in the UI/UX testing process. The author in [18] even stated that 
based on a study conducted by researchers from Harvard University, Covid-19 protocols such as physical distancing will last until 2022. This conditions certainly become obstacles and challenges in various sectors, including the software testing sector. UI/UX testing, which ideally be carried out in-person with respondents to get optimum feedback, should be carried out using another approach following the new normal protocol policy [19][20]. This can be overcome by conducting UI/UX testing with an unmoderated remote usability testing approach [21]. Unmoderated remote usability testing offers flexibility within time and distance constraints.

Based on the explanation above, the researcher decided to conduct usability testing on ONT UKNI application using an unmoderated remote testing approach. Unmoderated testing is a test where respondents try the product being tested and provide an assessment without being accompanied by a moderator [22]. The moderator creates a test scenario for respondents to follow who will then provide an assessment. Remote testing approach can solve problems related to distance since respondents can be located anywhere [23][24]. Thus, remote testing considered suitable to be used considering physical distancing protocol during Covid-19 pandemic situation. USE questionnaire instrument was used to obtain qualitative data then processed further to determine user experience in terms of usefulness, satisfaction, ease of use, and ease of learning. This research contributes to theoretical and practical basis of using USE questionnaire in unmoderated remote testing and encourages professionals to adopt this approach.

\section{ONT UKNI BACKGROUND}

Nursing education is one area that can benefited of Android applications as a learning media for the preparation of the Indonesian Nurses Competency Test (UKNI). UKNI is a process to determine whether or not someone is eligible to become a nurse in Indonesia [25]. The author in [26] stated that the graduation rate in 2018 was $57.1 \%$ with 26,208 graduates, in 2019 it was $58.6 \%$ with 29,240 graduates, and in 2020 it was $54.4 \%$ with 23,663 graduates. This figure is quite low considering the need for the nursing profession in Indonesia is quite high. Indonesian Central Statistics Agency predicts that the need for nurses in Indonesia is 48,253,428 nurses with a ratio of 180 nurses per 100,000 population [27]. The need for an additional number of nurses in Indonesia in 2019 is predicted to be 372,534 nurses [28]. This is in line with the statement of the Professor of the Faculty of Nursing Universitas Indonesia, Achir Yani Hamid, who stated that the number of Indonesian nursing personnel was only $60 \%$ of the total population where the world standard was 80\% [29].

The author in [30] stated that the obstacles faced by UKNI participants were lack of focus and lack of time to prepare, considering that most UKNI participants were students who were practicing the nursing profession. Another reason was the participants' ignorance about the UKNI concept, especially regarding the UKNI test grid. The author in [31], [32], and [33] analyze the factors that influence UKNI graduation, including try out, Grade Point Average, learning style, and learning motivation.
ONT UKNI was developed to overcome problems that have been stated before. It is a mobile application which has features such as learning material and try out simulation as shown in Fig. 1. Learning materials and try out given have been adapted to the material being tested at UKNI to provide real experience regarding nurse competency test.

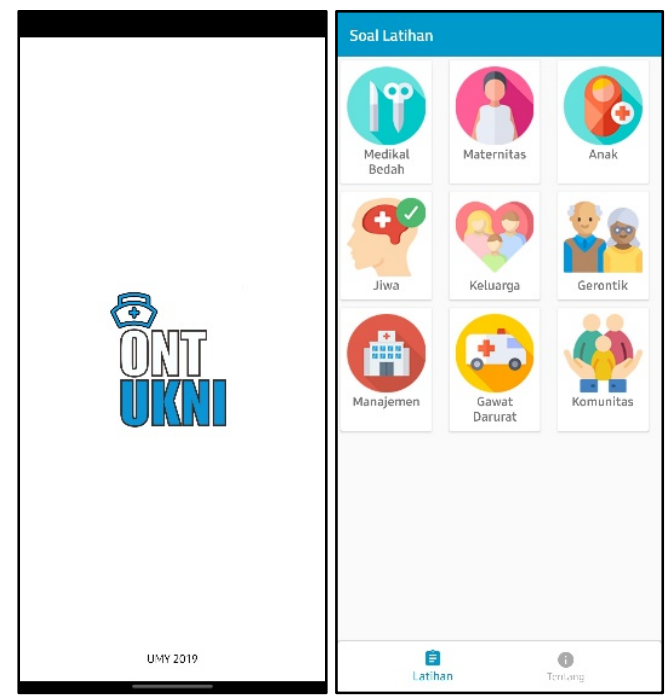

Fig. 1. ONT UKNI Mobile Application.

\section{METHODOLOGY}

This study used a four-step procedure. Fig. 2 shows the research methodology used in this study. The authors start from literature review, requirement analysis, usability testing and data tabulation, and analysis.

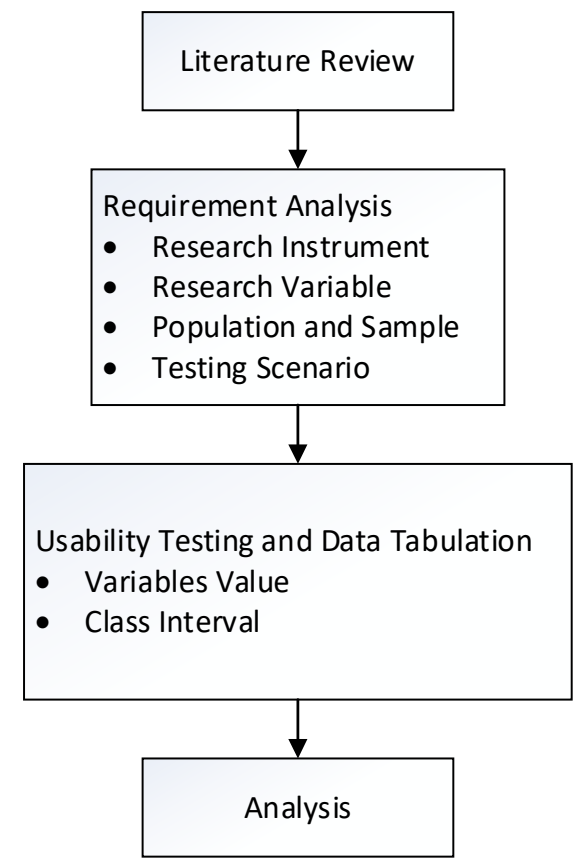

Fig. 2. Research Methodology.

\section{A. Literature Review}

The authors examine several theories sourced from books, reputable online sources, or journals. Several theories used in 
this research include usability testing, USE questionnaire, testing, population, sample, data tabulation. This stage also aims to explore and find references related to previous studies.

\section{B. Requirement Analysis}

Research instruments and variables will be determined in this phase. The research instrument used to perform usability testing on a number of respondents. Sample size of respondents were taken from the population who are potential users of ONT UKNI application. Respondents will be asked to perform several steps contained in the test scenario that has been given by the author. Respondents were given 30 days to try the ONT UKNI application with the aim of getting as much user experience as possible. After that the respondents will fill out a questionnaire provided by the author.

\section{Usability Test and Data Tabulation}

At this stage the respondents will fill out an online assessment questionnaire based on the experience they have gained while using ONT UKNI application. The usability testing process is carried out remotely using Google Forms and is not moderated by researchers. Calculation of the value of each variable used in usability testing is carried out. Each variable used will be categorized based on class intervals.

\section{Analysis}

Usability test and data tabulation results were analyzed to find out how the results of each research variable were used. Recommendations regarding applications were analyzed to give ONT UKNI developer insight.

\section{RESULTS AND DISCUSSION}

\section{A. Requirement Analysis}

1) Research instruments and variables: At this stage the authors determine the instruments and research variables used. The assessment scale used in the questionnaire is Likert scale with descriptive statements converted into numerical values as in Table I. USE questionnaire developed by Arnold M. Lund in 2001 was used as a test instrument [12]. USE questionnaire consists of 30 statements which are divided into four variables of assessment variables, namely: usefulness, ease of use, ease of learning, and satisfaction. Usability instrument has been modified according to the scope of the research as shown in Tables II to $\mathrm{V}$.

TABLE I. LIKERT SCALE ASSESSMENT CRITERIA

\begin{tabular}{|l|l|}
\hline Statement & Mark \\
\hline Strongly agree & 5 \\
\hline Agree & 4 \\
\hline Neutral & 3 \\
\hline Disagree & 2 \\
\hline Strongly Disagree & 1 \\
\hline
\end{tabular}

2) Research population: The population in this study were prospective users of ONT UKNI application, namely students of the nursing profession at the Universitas Muhammadiyah Yogyakarta who were at PKU Yogyakarta Hospital. This population was chosen because UKNI is a test for professional students to get nurse certification. Thus respondents were in a preparation for UKNI. From the entire population of nursing profession students of Universitas Muhammadiyah Yogyakarta who were interns at PKU, several samples taken to become respondents in usability testing.

TABLE II. USEFULNESS QUESTIONNAIRE INSTRUMENT

\begin{tabular}{|l|l|}
\hline No & Questions \\
\hline U1 & $\begin{array}{l}\text { Does ONT UKNI application help me to be more effective in } \\
\text { preparing for UKNI? }\end{array}$ \\
\hline U2 & $\begin{array}{l}\text { Does ONT UKNI application help me to be more productive in } \\
\text { preparing for UKNI? }\end{array}$ \\
\hline U3 & ONT UKNI application is very useful in preparing for UKNI. \\
\hline U4 & $\begin{array}{l}\text { ONT UKNI application makes me more flexible in managing my } \\
\text { study time to face UKNI. }\end{array}$ \\
\hline U5 & $\begin{array}{l}\text { ONT UKNI application makes the learning process to deal with } \\
\text { UKNI easier to do. }\end{array}$ \\
\hline U6 & ONT UKNI application saves me time in preparation for UKNI. \\
\hline U7 & ONT UKNI application fulfills my needs in preparation for UKNI. \\
\hline U8 & $\begin{array}{l}\text { ONT UKNI app did a lot of what I expected with regards to UKNI } \\
\text { preparation. }\end{array}$ \\
\hline
\end{tabular}

TABLE III. EASE OF USE QUESTIONNAIRE INSTRUMENT

\begin{tabular}{|l|l|}
\hline No & Questions \\
\hline EU1 & ONT UKNI application is easy to use. \\
\hline EU2 & ONT UKNI application is practical to use. \\
\hline EU3 & ONT UKNI application is user friendly. \\
\hline EU4 & $\begin{array}{l}\text { ONT UKNI application requires a few steps when I want to use a } \\
\text { feature in the application. }\end{array}$ \\
\hline EU5 & This application is very flexible. \\
\hline EU6 & Using ONT UKNI application does not require a lot of effort. \\
\hline EU7 & $\begin{array}{l}\text { I can use ONT UKNI application without requiring written } \\
\text { instructions or guidance. }\end{array}$ \\
\hline EU8 & I did not find any inconsistencies in ONT UKNI application. \\
\hline EU9 & $\begin{array}{l}\text { Users who regularly or only occasionally use ONT UKNI } \\
\text { application will love this application. }\end{array}$ \\
\hline EU10 & I can solve errors in using ONT UKNI application easily. \\
\hline EU11 & I managed to use ONT UKNI app every time. \\
\hline
\end{tabular}

TABLE IV. EASE OF LEARNING QUESTIONNAIRE INSTRUMENT

\begin{tabular}{|l|l|}
\hline No & Questions \\
\hline EL1 & I was able to quickly learn how to use ONT UKNI app. \\
\hline EL2 & I can easily remember how to use ONT UKNI application. \\
\hline EL3 & ONT UKNI application is easy to learn. \\
\hline EL4 & I quickly became proficient in using ONT UKNI application. \\
\hline
\end{tabular}


TABLE V. SATISFACTION QUESTIONNAIRE INSTRUMENT

\begin{tabular}{|l|l|}
\hline No & Questions \\
\hline S1 & I am satisfied with ONT UKNI application. \\
\hline S2 & I will recommend ONT UKNI application to my friends. \\
\hline S3 & Using ONT UKNI application is very fun. \\
\hline S4 & ONT UKNI app worked as I expected. \\
\hline S5 & ONT UKNI application has a nice display. \\
\hline S6 & I feel the need to use ONT UKNI application in preparation for UKNI. \\
\hline S7 & ONT UKNI application is convenient to use in preparing for UKNI. \\
\hline
\end{tabular}

3) Sample size: The sampling technique used is simple random sampling where each member of the population has the same opportunity to become a respondent. The size of sample is determined using the Slovin formula approach as described as in (1).

$n=\frac{N}{1+N(e)^{2}}$

Where:

$\mathrm{n}=$ Sample size

$\mathrm{N}=$ Population Size

$\mathrm{e}=$ error rate

The population size of nursing profession students at Muhammadiyah Yogyakarta University who are at PKU Yogyakarta Hospital is 27 students. The error rate used in the search for the sample size is $5 \%$. By using (1), it can be calculated the sample size used in the usability test. The sample size used was 25.292 respondents which were rounded up to 26 respondents.

$\mathrm{n}=\frac{27}{1+27(0,05)^{2}}=25,292$

4) Testing scenario: Testing is carried out without moderation and remotely considering the Covid-19 pandemic situation. Remote testing is possible in the presence of a test scenario [34]. Test scenario consists of 8 steps in a task-based form and aims to ensure that respondents have tried and understood the features of ONT UKNI application. Table VI shows the scenarios that will be carried out by respondents remotely without moderation. Test scenario is made as simple as possible to make it easier for respondents to follow and does not require any clarification from researchers [24][35]. 26 respondents in this study carried out a number of activities following the scenario given by the research team. Respondents were given 14 days to try ONT UKNI application and carry out the given scenario and try ONT UKNI application. After 14 days, the respondent will assess the usability of ONT UKNI application using the provided instrument.

\section{B. Usability Testing and Data Tabulations}

Tables VII to X shows post-usability test results that were tabulated and compiled. From the test results, it can be calculated the value of each variable used. Equation (2) used to determine the usability variable, ease of use, ease of learning, and satisfaction value.

Nilai Variabel $=\frac{\mathrm{s}}{\mathrm{nr} x \mathrm{np}}$

Where:

$\mathrm{s}=$ Total value

$\mathrm{nr}=$ Number of respondents

$\mathrm{np}=$ Number of statements

Usefulness variable value $=\frac{876}{26 \times 8}=4,21$

Ease of Use variable value $=\frac{1190}{26 \times 11}=4,16$

Ease of Learning variable value $=\frac{447}{26 \times 4}=4,29$

Satisfaction variable value $=\frac{766}{26 \times 7}=4,20$

TABLE VI. TASK SCENARIO

\begin{tabular}{|l|l|}
\hline No & Scenario \\
\hline 1 & Downloading the ONT UKNI application apk that has been shared \\
\hline 2 & Installing ONT UKNI application \\
\hline 3 & Running ONT UKNI application \\
\hline 4 & Try the study menu \\
\hline 5 & Try the training menu \\
\hline 6 & Checking the value of the results of the exercise and discussion \\
\hline 7 & Try the menu about developer \\
\hline 8 & Exit UKNI ONT app \\
\hline
\end{tabular}


TABLE VII. USEFULNESS (U)

\begin{tabular}{|c|c|c|c|c|c|c|c|c|c|c|}
\hline \multirow{2}{*}{ No } & \multicolumn{5}{|l|}{ Likert Scale } & \multirow{2}{*}{$\mathbf{N}$} & \multirow{2}{*}{ Min } & \multirow{2}{*}{ Max } & \multirow{2}{*}{ Mean } & \multirow{2}{*}{ SD } \\
\hline & Strongly Agree & Agree & Neutral & Disagree & Strongly Disagree & & & & & \\
\hline $\mathrm{U} 1$ & 8 & 16 & 1 & 0 & 1 & 26 & 1 & 5 & 4,15 & 0,818 \\
\hline U2 & 6 & 18 & 1 & 0 & 1 & 26 & 1 & 5 & 4,08 & 0,781 \\
\hline U3 & 9 & 15 & 2 & 0 & 0 & 26 & 3 & 5 & 4,27 & 0,592 \\
\hline $\mathrm{U} 4$ & 8 & 16 & 1 & 1 & 0 & 26 & 2 & 5 & 4,19 & 0,680 \\
\hline U5 & 9 & 14 & 2 & 1 & 0 & 26 & 2 & 5 & 4,19 & 0,735 \\
\hline U6 & 11 & 14 & 1 & 0 & 0 & 26 & 3 & 5 & 4,38 & 0,560 \\
\hline $\mathrm{U} 7$ & 7 & 17 & 1 & 1 & 0 & 26 & 2 & 5 & 4,15 & 0,662 \\
\hline U8 & 9 & 16 & 0 & 1 & 0 & 26 & 2 & 5 & 4,27 & 0,654 \\
\hline
\end{tabular}

TABLE VIII. EASE OF USE (EU)

\begin{tabular}{|c|c|c|c|c|c|c|c|c|c|c|}
\hline \multirow{2}{*}{ No } & \multicolumn{5}{|l|}{ Likert Scale } & \multirow{2}{*}{$\mathbf{N}$} & \multirow{2}{*}{ Min } & \multirow{2}{*}{ Max } & \multirow{2}{*}{ Mean } & \multirow{2}{*}{ SD } \\
\hline & Strongly Agree & Agree & Neutral & Disagree & Strongly Disagree & & & & & \\
\hline EU1 & 10 & 13 & 2 & 1 & 0 & 26 & 1 & 5 & 4,23 & 0,750 \\
\hline EU2 & 6 & 18 & 2 & 0 & 0 & 26 & 1 & 5 & 4,15 & 0,533 \\
\hline EU3 & 11 & 13 & 1 & 1 & 1 & 26 & 3 & 5 & 4,31 & 0,722 \\
\hline EU4 & 7 & 17 & 1 & 1 & 1 & 26 & 2 & 5 & 4,15 & 0,662 \\
\hline EU5 & 6 & 18 & 2 & 0 & 0 & 26 & 3 & 5 & 4,15 & 0,533 \\
\hline EU6 & 5 & 20 & 0 & 1 & 0 & 26 & 2 & 5 & 4,12 & 0,577 \\
\hline EU7 & 7 & 19 & 0 & 0 & 0 & 26 & 4 & 5 & 4,27 & 0,444 \\
\hline EU8 & 6 & 17 & 1 & 1 & 1 & 26 & 1 & 5 & 4,00 & 0,877 \\
\hline EU9 & 7 & 16 & 3 & 0 & 0 & 26 & 3 & 5 & 4,15 & 0,601 \\
\hline EU10 & 6 & 18 & 2 & 0 & 0 & 26 & 3 & 5 & 4,15 & 0,533 \\
\hline EU11 & 7 & 15 & 3 & 1 & 0 & 26 & 2 & 5 & 4,08 & 0,730 \\
\hline
\end{tabular}

TABLE IX. EASE OF LEARNING (EL)

\begin{tabular}{|c|c|c|c|c|c|c|c|c|c|c|}
\hline \multirow{2}{*}{ No } & \multicolumn{5}{|l|}{ Likert Scale } & \multirow{2}{*}{$\mathbf{N}$} & \multirow{2}{*}{ Min } & \multirow{2}{*}{ Max } & \multirow{2}{*}{ Mean } & \multirow{2}{*}{ SD } \\
\hline & Strongly Agree & Agree & Neutral & Disagree & Strongly Disagree & & & & & \\
\hline EL1 & 8 & 16 & 1 & 1 & 0 & 26 & 1 & 5 & 4,19 & 0,680 \\
\hline EL2 & 11 & 15 & 0 & 0 & 0 & 26 & 4 & 5 & 4,42 & 0,494 \\
\hline EL3 & 10 & 14 & 2 & 0 & 0 & 26 & 3 & 5 & 4,31 & 0,606 \\
\hline$\overline{\text { EL4 }}$ & 9 & 15 & 2 & 0 & 0 & 26 & 3 & 5 & 4,27 & 0,592 \\
\hline
\end{tabular}

TABLE X. SATISFACTION (S)

\begin{tabular}{|c|c|c|c|c|c|c|c|c|c|c|}
\hline \multirow{2}{*}{ No } & \multicolumn{5}{|l|}{ Likert Scale } & \multirow{2}{*}{$\mathbf{N}$} & \multirow{2}{*}{ Min } & \multirow{2}{*}{ Max } & \multirow{2}{*}{ Mean } & \multirow{2}{*}{ SD } \\
\hline & Strongly Agree & Agree & Neutral & Disagree & Strongly Disagree & & & & & \\
\hline S1 & 7 & 16 & 0 & 2 & 1 & 26 & 1 & 5 & 4,00 & 0,961 \\
\hline S2 & 8 & 16 & 2 & 0 & 0 & 26 & 3 & 5 & 4,23 & 0,576 \\
\hline S3 & 8 & 15 & 3 & 0 & 0 & 26 & 3 & 5 & 4,19 & 0,621 \\
\hline S4 & 8 & 16 & 1 & 0 & 1 & 26 & 1 & 5 & 4,15 & 0,818 \\
\hline S5 & 7 & 17 & 1 & 1 & 0 & 26 & 2 & 5 & 4,15 & 0,662 \\
\hline S6 & 11 & 14 & 1 & 0 & 0 & 26 & 3 & 5 & 4,38 & 0,560 \\
\hline S7 & 10 & 15 & 1 & 0 & 0 & 26 & 3 & 5 & 4,35 & 0,551 \\
\hline
\end{tabular}

To be able to determine the category of assessment class based on known variable values, a class interval size is needed [36]. Equation (3) shows the formula used to calculate the length of the class interval.

$\mathrm{P}=\frac{\mathrm{Dx}-\mathrm{Dy}}{\mathrm{n}}$

Where:

$\mathrm{P}=$ Interval length
$\mathrm{Dx}=$ Biggest value

Dy $=$ Smallest value

$\mathrm{n}=$ Number of classes

$\mathrm{P}=\frac{5-1}{5}$

$\mathrm{P}=0,8$ 
Based on $\mathrm{P}=0.8$ obtained from (3), an assessment table of the results of the usability test analysis can be made which is then used to determine the category of each variable. Table XI shows the length of the interval for each category. Table XII shows the results of the analysis carried out. The usability variable gets a value of 4.21 and is included in the good category class interval. The ease of use variable gets a value of 4.16 and is included in the good class interval. The ease of learning variable got a value of 4.29 and was included in the good class interval. The satisfaction variable gets a value of 4.20 and is included in the very good class interval.

TABLE XI. ClASS INTERVAL LENGTH

\begin{tabular}{|l|l|l|}
\hline No & Interval Length & Category \\
\hline 1 & $1.00-1.79$ & Very low \\
\hline 2 & $1.80-2.59$ & Low \\
\hline 3 & $2.60-3.39$ & Pretty good \\
\hline 4 & $3.40-4.19$ & Good \\
\hline 5 & $4.20-5.00$ & Very good \\
\hline
\end{tabular}

TABLE XII. VARIABLE CATEGORY BASED ON INTERVAL

\begin{tabular}{|l|l|l|l|l|}
\hline No & Variable & Total Value & Average Value & Category \\
\hline 1 & Utility & 876 & 4.21 & Very good \\
\hline 2 & Ease of Use & 1190 & 4.16 & Good \\
\hline 3 & Ease of Learning & 447 & 4.29 & Very good \\
\hline 4 & Satisfaction & 766 & 4.20 & Very good \\
\hline \multicolumn{2}{|l|}{ Average variable value } & 4.21 & Very good \\
\hline
\end{tabular}

Usefulness variable gets a value of 4.21 and is included in the Very Good category. ONT UKNI application has learning and tries out features that are in accordance with the needs of application users who are students of the nursing profession in preparation for joining UKNI. In addition, ONT UKNI application has discussion feature so that users will better understand the questions and exact answers given which are very useful, efficient, and can increase user productivity in the preparation for UKNI. One aspect that needs to be considered is the aspect of the responsiveness. Application responsiveness is one of the factors that cam further increase user productivity and efficiency in using applications [7].

Ease of use variable gets a value of 4.16 and falls into the Good category. Button design and layout is easy to reach. It has minimalist feature by having 2 main buttons for the main features, namely the learning feature and the try out feature. Users can also use the application even though it is not accompanied by a user guide and at any time. Consistent selection of text and colors also helps users. However, there are still some areas that could be improved. Color selection and interface design are 2 factors that have the potential to be improved to provide better interaction and user experience [37].

Ease of learning variable gets a value of 4.29 and was included in the Very Good category. It shows that ONT UKNI easy for user to understand. It is intuitive enough for first time user to follow. The application has a consistent design which helps user to get familiar faster which is an important aspect in ease of learning [38]. The placement of buttons accompanied by text makes it easier for users in the learning process to use this application. In addition, the selection of clear and contrasting colors between the buttons, written text, and background also helps the use of ONT UKNI application.

Satisfaction variable gets a value of 4.20 and is included in the Very Good category. ONT UKNI application was built with the aim of helping students of the nursing profession in dealing with UKNI. Based on the test results, it can be seen that users feel confident to use ONT UKNI application in preparation for UKNI. Application design that is attractive, easy to use, and easy to learn is also a factor that determines user satisfaction [39].

\section{CONCLUSION AND FUtURE WORK}

This study was aimed to conduct usability testing on ONT UKNI application. The test has been carried out on 26 respondents who are nursing profession students of Universitas Muhammadiyah Yogyakarta who were interns at PKU Yogyakarta Hospital. The test was conducted using a USE questionnaire remotely and without any moderation from the research team. USE questionnaire gives insight on 4 variables, namely usefulness, ease of use, ease of learning, and satisfaction. The usability variable gets a value of 4.21 and is included in the Very Good category. The ease of use variable gets a value of 4.16 and falls into the Good category. The ease of learning variable got a value of 4.29 and was included in the Very Good category. The satisfaction variable gets a value of 4.20 and is included in the Very Good category. However, there are several areas to improve the user experience of ONT UKNI application, such as color selection, application interface design, and implementation of gamification into ONT UKNI application. Overall, usability testing with unmoderated remote testing approach using USE questionnaire can be done and able to provide information about areas that users are satisfied with or areas that need improvement.

Future work should focus on improving ONT UKNI application by redesign UI and implementing gamification. Further test with intervention using quasi experiment also possible to be conducted to see whether ONT UKNI application really meets its purpose, which is to help nursing profession student preparing for UKNI.

\section{ACKNOWLEDGMENT}

The authors gratefully acknowledge Universitas Ahmad Dahlan for funding assistance in this research and School of Nursing Universitas Muhammadiyah Yogyakarta for research collaboration.

\section{REFERENCES}

[1] M. Elgan, "With Smartphones Like This, Why Do We Need Laptops?," 2017. https://www.computerworld.com/article/3241233/smartphones/ with-smartphones-like-these-why-do-we-need-laptops.html (accessed Jan. 24, 2019).

[2] S. Muyaroah and M. Fajartia, "Pengembangan Media Pembelajaran Berbasis Android dengan menggunakan Aplikasi Adobe Flash CS 6 pada Mata Pelajaran Biologi Abstrak,” vol. 6, no. 2301, pp. 79-83, 2017.

[3] A. Teodorescu, "Mobile learning and its impact on business English learning,” Procedia - Soc. Behav. Sci., vol. 180, no. November 2014, pp. 1535-1540, 2015, doi: 10.1016/j.sbspro.2015.02.303. 
[4] J. Kuswanto and F. Radiansah, "Media Pembelajaran Berbasis Android Pada Mata Pelajaran Sistem Operasi Jaringan Kelas XI,” An Nabighoh J. Pendidik. dan Pembelajaran Bhs. Arab, vol. 14, no. 01, p. 129, 2018.

[5] A. Relawati and G. M. Zamroni, "Development of Android Based Online Nurse Test Preparation,” JUITA J. Inform., vol. 8, no. 1, p. 111, 2020, doi: 10.30595/juita.v8i1.6795.

[6] B. Igler, T. Braumann, and S. Bohm, "Evaluating the Usability of Mobile Applications Without Affecting The User And The Usage Context Bodo,” Int. J. Bus. Manag. Stud., vol. 5, no. 1, pp. 92-102, 2013.

[7] N. D. Lynn, A. I. Sourav, and D. B. Setyohadi, "Increasing user satisfaction of mobile commerce using usability," Int. J. Adv. Comput. Sci. Appl., vol. 11, no. 8, pp. 300-308, 2020, doi: 10.14569/IJACSA.2020.0110839.

[8] S. A. Wicaksono, D. R. Firdausy, and M. C. Saputra, "Usability Testing on Android Application of Infrastructure and Facility Reporting Management Information System,” J. Inf. Technol. Comput. Sci., vol. 3, no. 2, pp. 184-193, 2018, doi: 10.25126/jitecs.20183267.

[9] W. A. Kusuma, V. Noviasari, and G. I. Marthasari, "Analisis Usability dalam User Experience pada Sistem KRS- Online UMM menggunakan USE Questionnaire,” vol. 5, no. 4, pp. 294-301, 2016.

[10] K. Aelani and K. Kunci, "Pengukuran Usability Sistem Menggunakan Use Questionnaire (Studi Kasus Aplikasi Perwalian Online STMIK \&quot; AMIKBANDUNG \&quot; )," Semin. Nas. Apl. Teknol. Inf., vol. 2012, no. Snati, pp. 1907-5022, 2012, [Online]. Available: http://journal.uii.ac.id/Snati/article/viewFile/2913/2676.

[11] M. Gao, P. Kortum, and F. Oswald, "Psychometric evaluation of the USE (usefulness, satisfaction, and ease of use) questionnaire for reliability and validity,” Proc. Hum. Factors Ergon. Soc., vol. 3, pp. 1414-1418, 2018, doi: 10.1177/1541931218621322.

[12] A. M. Lund, "Measuring usability with the USE questionnaire," Usability interface, vol. 8, no. 2, pp. 3-6, 2001, doi: 10.1177/1078087402250360.

[13] M. Nur, F. Abd, A. Hussain, M. Maizan, and F. Hamdi, "Usability study of youtube websites for Malaysian teenagers Usability Study of YouTube Websites For Malaysian Teenagers,” vol. 020121, no. October, 2017.

[14] T. Yuliyana, I. K. R. Arthana, and K. Agustini, "Usability Testing pada Aplikasi POTWIS,” JST (Jurnal Sains dan Teknol., vol. 8, no. 1, p. 12, 2019, doi: 10.23887/jst-undiksha.v8i1.12081.

[15] B. Laugwitz, T. Held, and M. Schrepp, "Construction and Evaluation of a User Experience Questionnaire,” Lncs, vol. 5298, p. 2007, 2007, [Online]. Available: http://citeseerx.ist.psu.edu/viewdoc/download?doi= 10.1.1.472.3719\&rep=rep1\&type=pdf.

[16] W. A. Pramono, H. M. Az-zahra, and R. I. Rokhmawati, "Evaluasi Usability pada Aplikasi MyTelkomsel dengan Menggunakan Metode Usability Testing,” J. Pengemb. Teknol. Inf. dan Ilmu Komput., vol. 3, no. 3, pp. 2951-2959, 2019.

[17] K. Ishaq, N. A. M. Zin, F. Rosdi, A. Abid, and Q. Ali, "Usability of mobile assisted language learning app,” Int. J. Adv. Comput. Sci. Appl., vol. 11, no. 1, pp. 354-363, 2020, doi: 10.14569/ijacsa.2020.0110145.

[18] G. Intan, “Bagaimana Kehidupan Pasca Pandemi Covid-19?,” Voice of America, 2020. https://www.voaindonesia.com/a/bagaimana-kehidupanpasca-pandemi-covid-19-/5393460.html (accessed Mar. 01, 2021).

[19] World Health Organization, “New Normal,” who.int, 2020. https://www.who.int/indonesia/news/novel-coronavirus/newinfographics/new-normal.

[20] kemsos.go.id, "What is New Normal?," Kementrian Sosial Republik Indonesia, 2020. https://www.kemsos.go.id/en/what-is-new-normal.
[21] A. Schade, "Remote Usability Tests: Moderated and Unmoderated," Nielsen Norman Group, 2013. https://www.nngroup.com/articles/remote -usability-tests/ (accessed Jan. 26, 2022).

[22] N. Babich, "Usability Testing: Moderated vs Unmoderated," medium.com, 2020. https://medium.com/thinking-design/usabilitytesting-moderated-vs-unmoderated-adbccc37404b (accessed Jul. 09, 2021).

[23] K. Whitenton, “Tools for Unmoderated Usability Testing," Nielsen Norman Group, 2019. https://www.nngroup.com/articles/unmoderateduser-testing-tools/ (accessed Jan. 26, 2022).

[24] J. M. C. Bastien, "Usability testing: a review of some methodological and technical aspects of the method,” Int. J. Med. Inform., vol. 79, no. 4, 2010, doi: 10.1016/j.ijmedinf.2008.12.004.

[25] Minister of Education and Culture of the Republic of Indonesia, "Regulation of the Minister of Education and Culture of the Republic of Indonesia Number 2 of 2020 Concerning Procedures for Implementing Competency Test for Health Students,” 2020.

[26] RISTEKDIKTI, "Data Statistik UKNI," 2021. http://ukners.ristekdikti.go.id/statistik (accessed Jan. 21, 2019).

[27] L. F. Manalu, "Menyikapi Krisis Kekurangan Perawat," SINDOnews, 2017. https://nasional.sindonews.com/read/1210047/18/menyikapikrisis-kekurangan-perawat-1496348683 (accessed Jan. 23, 2018).

[28] who.int, "Rencana Pengembangan Tenaga Kesehatan Tahun 20112025,” 2011.

[29] K. Rajagukguk, "Indonesia Kekurangan Jumlah Tenaga Perawat," Media Group, 2020. https://mediaindonesia.com/humaniora/314345/ indonesia-kekurangan-jumlah-tenaga-perawat (accessed Feb. 02, 2021).

[30] S. Kholifah and W. Kusumawati, "Hambatan Lulusan Ners Dalam Menghadapi Uji Kompetensi Ners Indonesia,” Indones. J. Heal. Sci., vol. 7, no. 1, pp. 40-47, 2016.

[31] A. Abdillah, "Analisis Faktor-Faktor Yang Mempengaruhi Kelulusan Uji Kompetensi Ners Indonesia,” J. Penelit. Adm. Publik, vol. 2, no. 2, pp. 373-380, 2016, doi: 10.1038/nature07345.

[32] L. Hakim and L. S. Pusporini, "Analisis Faktor Yang Mempengaruhi Capaian Kelulusan Uji Kompetensi Ners Mahasiswa Program Profesi Ners,” Cakrawala Pendidik., vol. 37, no. 2, 2018, doi: 10.21831/cp.v37i2.19881.

[33] A. Hartina, T. Tahir, N. Nurdin, and M. Djafar, "Faktor Yang Berhubungan Dengan Kelulusan Uji Kompetensi Ners Indonesia (Ukni) Di Regional Sulawesi,” J. Persat. Perawat Nas. Indones., vol. 2, no. 2, p. 65, 2018, doi: 10.32419/jppni.v2i2.84.

[34] H. A. Alzahrani and R. A. Alnanih, "A Design Study to Improve user Experience of a Procedure Booking Software in Healthcare," Int. J. Adv. Comput. Sci. Appl., vol. 11, no. 11, pp. 245-254, 2020, doi: 10.14569/IJACSA.2020.0111132.

[35] K. Moran and K. Pernice, "Remote Moderated Usability Tests: Why to Do Them,” Nielsen Norman Group, 2020. https://www.nngroup.com/ articles/moderated-remote-usability-test-why/ (accessed Jan. 26, 2022).

[36] Sudjana, Metode Statistika. Bandung: Tarsito, 2002.

[37] A. Al-Hunaiyyan, R. Alhajri, B. Alghannam, and A. Al-Shaher, "Student Information System: Investigating User Experience (UX)," Int. J. Adv. Comput. Sci. Appl., vol. 12, no. 2, pp. 80-87, 2021, doi: 10.14569/IJACSA.2021.0120210.

[38] M. S. Bashir and A. Farooq, "EUHSA: Extending Usability Heuristics for Smartphone Application,” IEEE Access, vol. 7, pp. 100838-100859, 2019, doi: 10.1109/ACCESS.2019.2923720.

[39] J. Nielsen, “Usability Engineering,” Nielsen Norman Group, 1993. https://www.nngroup.com/books/usability-engineering/ (accessed Jan. 02, 2022). 